Institute for Employment Research

The Research Institute of the

\title{
IAB-Discussion Paper 19/2010
}

Articles on labour market issues

\section{Parental risk attitudes and children's secondary school track choice}

Guido Heineck

Oliver Wölfel 


\title{
Parental risk attitudes and children's secondary school track choice
}

\author{
Guido Heineck (IAB) \\ Oliver Wölfel (IAB)
}

Mit der Reihe „IAB-Discussion Paper“ will das Forschungsinstitut der Bundesagentur für Arbeit den Dialog mit der externen Wissenschaft intensivieren. Durch die rasche Verbreitung von Forschungsergebnissen über das Internet soll noch vor Drucklegung Kritik angeregt und Qualität gesichert werden.

The "IAB Discussion Paper" is published by the research institute of the German Federal Employment Agency in order to intensify the dialogue with the scientific community. The prompt publication of the latest research results via the internet intends to stimulate criticism and to ensure research quality at an early stage before printing. 


\section{Contents}

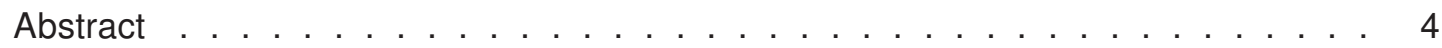

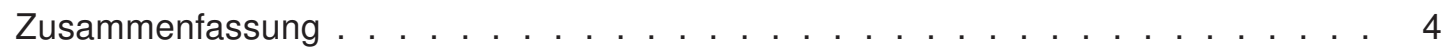

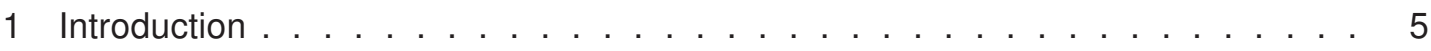

2 The German school system . . . . . . . . . . . . . . . . . . . . . . . . . . . . . . 6

3 Risk preferences and educational outcomes $\ldots \ldots \ldots$

4 Data and methods . . . . . . . . . . . . . . . . . . . . 9

5 Results . . . . . . . . . . . . . . . . . . . . . . 12

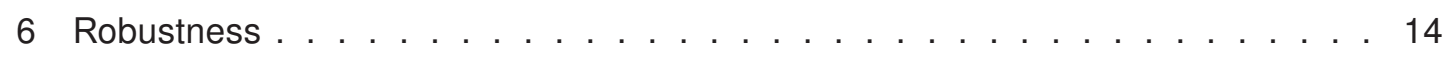

7 Summary and conclusions . . . . . . . . . . . . . . . . 16

References . . . . . . . . . . . . . . . . . . . . . . . 28

A Appendix ............................. 31 


\section{Abstract}

It is well known that individuals' risk attitudes are related to behavioral outcomes such as smoking, portfolio decisions, and also educational attainment, but there is barely any evidence on whether parental attitudes affect the educational attainment of dependent children. We add to this literature and examine whether parents' risk attitudes relate to children's secondary school track choice in Germany where tracking occurs at age ten and has a strong binding character. Our results indicate mainly no effects of paternal risk preferences but a strong negative impact of maternal risk aversion on children's enrollment in upper secondary school.

\section{Zusammenfassung}

In zahlreichen Studien zeigt sich der Einfluss von Risikobereitschaft auf individuelles Verhalten in unterschiedlichen Bereichen wie etwa Rauchen, Portfolioinvestitionen und auch Bildungsentscheidungen. Es gibt jedoch kaum Evidenz darüber, ob und welchen Einfluss Risikoeinstellungen von Eltern auf das Bildungsverhalten von Kindern ausüben. In der vorliegenden Studie untersuchen wir nun die Auswirkungen der elterlichen Risikoeinstellung auf die Sekundärschulwahl von Kindern. Die Ergebnisse deuten auf keinen großen Einfluss der väterlichen Risikoeinstellung hin, jedoch auf substantiell negative Auswirkungen mütterlicher Risikoaversion auf die Wahl des Gymnasiums.

JEL classification: $121, \mathrm{~J} 24$

Keywords: educational choice, risk attitudes, SOEP

Acknowledgements: We would like to thank Regina T. Riphahn, Stefanie Gundert and Christoph Wunder as well as conference participants at the International Workshop on Applied Economics of Education (IWAEE) and at the Annual Meeting of the German Statistical Society for helpful comments and suggestions. The usual disclaimer applies. 


\section{Introduction}

The decision about which educational path children should follow has far-reaching consequences into their future adult life, and in particular so in countries with early tracking such as Germany. If later revision of the decision is costly so that upward mobility between tracks is low, early tracking largely predetermines students' final secondary schooling achievement and their vocational or academic career. Children's future social and economic situation therefore strongly depends on the "right" school track choice.

With respect to the determinants of this choice, one comes across a vast literature on the transmission of socio-economic status suggesting for high social selectivity. ${ }^{1}$ This means that parental education, as a compound measure for parents' cognitive skills and for investments into their children, is still the most important factor for children's educational attainment (e.g. Heineck/Riphahn, 2009, for Germany; Ermisch/Francesconi, 2001, for the UK). In addition, there are studies that e.g. look at the influence of family income (Acemoglu/Pischke, 2001: Blanden/Greaa. 2004) or parental (un)emplovment (Bratberg/Anti Nilsen/Vaage, 2008; Coelli, 2010) on children's education. Apart from that, there is barely any research in economics addressing whether parental attitudes towards education or other, possibly non-cognitive skills matter for their children's secondary schooling. ${ }^{2}$

Educational decisions might however be considered as investment with uncertain outcomes, which may then be subject to individuals' risk preferences. Everything else constant, it is therefore plausible to assume that risk preferences will also matter if individuals have to decide on their children's educational paths. The direction of the effect, however, is unclear a priori. If future returns are uncertain, risk averse individuals might more likely choose a less risky schooling path (either for themselves or for their children) where less risky might refer to both a shorter time spent in education and lower ability requirements. On the other hand, there is pervasive evidence on the positive effects of education on labor market success, so that it might also be that education is used as "safe haven", i.e. has an insurance character.

Given these two contradictory notions, it is unsurprising that the few empirical studies that address the relationship between individuals' risk attitudes and their own educational outcomes yield ambiguous findings (Belzil, 2007; Brown/Ortiz/Tavlor, 2006, see in more detail below). Beyond that we are aware of only one prior study by Leonardi (2007) who examines the relationship between parents' risk preferences and their children's secondary schooling track. Using data from the Bank of Italy Survey of Income and Wealth (SHIW), he concludes that parental risk attitudes are no major determinant of school track choice.

We add to this scarce literature using data from Germany. Again, this is interesting and relevant, since 1) the German educational system streams children in different schooling

\footnotetext{
In economics, intergenerational mobility research has a focus mainly on income (see the work of Solon (1992) which has initiated a large body of research) whereas it is social class mobility that is of interest in the sociological literature (for example, Erikson/Goldthorpe, 2002)

2 Yet, there is interest into this issue in sociology showing that, for example, parents' educational aspirations matter (Henz/Maas, 1995; Paulus/Blossfeld, 2007).
} 
tracks at age ten, i.e. very early in the life course and 2) mobility between tracks is low so that the initial choice has a strong predetermining character. In contrast to previous research, where risk attitudes are usually derived from hypothetical lottery scenarios, we employ the individuals' willingness to take risks in their career, which we believe to be a more appropriate indicator than the overall risk attitude.

Our results indicate that fathers' risk preferences play mainly no consistent role for children's secondary schooling track choice which is in line with Leonardi (2007). We however find a substantial negative effect of maternal risk aversion on the probability of choosing the upper secondary, i.e. the university qualifying school track.

The remainder of the paper is organized as follows: We next briefly introduce the German school system. Section 3 outlines the role of risk preferences for educational outcomes and gives a short overview of prior research. In section 4 , we introduce data and methods. Section 5 provides the estimation results, and section 6 discusses robustness checks. We conclude in section 7 .

\section{The German school system}

Education in Germany is not the own responsibility of the federal government but each of the 16 federal states is in charge for its educational system. However, the main features of the educational system are nearly identical: Children between age three and six might, but most not attend pre-school kindergarten. Compulsory school attendance begins with entrance into elementary school at the age of six, and ends at the age of 16 . Between age six and ten, i.e. from grade one to four ${ }^{3}$ education in elementary school provides basic training in reading, writing, basic mathematical skills, as well as in creative and technical subjects such as music, sports, painting and practical work.

\section{[Figure 1 about here]}

After completing primary school, school tracking sets in and children are streamed into different secondary schooling tracks (Figure 1), based on parents' preferred choices and teachers' recommendation that is given at the end of elementary school. This recommendation, which is binding in some but not all federal states ${ }^{4}$ is to be based on students' abilities so that the recommended secondary school track should be the most suitable for the student. The three dominant secondary school types are lower secondary school (Hauptschule), intermediate secondary school (Realschule), and upper secondary school (Gymnasium), which cover about 80 percent of students. ${ }^{5}$

3 In two federal states, Berlin and Brandenburg, elementary schooling ends at age twelve, i.e. the end of grade six.

4 In 2004, it was binding in four (Bavaria, Baden-Württemberg, Saxony, Thuringia) out of sixteen federal states, but parents can challenge the recommendation for example via an assessment by specialized teachers or by entrance exams for the school track they want to have their child attend.

5 Other school types include comprehensive schools, special schools and some few other, mainly private 
Lower secondary school as well as intermediate secondary school lasts for five to six years and provides the basis for further (blue and white collar) vocational apprenticeship training. Upper secondary school track lasts for nine years ${ }^{6}$ and provides - with the Abitur as graduation certificate - the fastest and direct path to tertiary education on universities and universities of applied sciences (Fachhochschulen).

In general, transition between secondary schooling tracks is possible although requirements differ across states. Individuals can for example 'upgrade' in a couple of federal states: After completion of lower secondary school, students can achieve the intermediate schooling degree (Mittlere Reife) within one additional year. Transition to the upper secondary schooling track from both lower and intermediate secondary track is also possible but subject to entrance requirements, such as having achieved a specific grade level and having a good command of a another foreign language in addition to English. Now, although transition between tracks is possible after the initial track choice, it is rare (Bellenberg/Hovestadt/Klemm, 2004) and thus predetermines students' final educational attainment to a large extent. ${ }^{7}$ Parents' preferences and attitudes, including their attitudes towards risk therefore play a major role in this decision process and their children's future education outcome.

\section{Risk preferences and educational outcomes}

It is a well-known fact that educational attainment correlates strongly with labor market success: No or lower educational attainment is associated to a higher risk of unemployment and to unstable and low-paid jobs. In contrast, higher education is a good predictor for access to well-paid and stable jobs with good career prospects. Why then should individuals not be willing to invest in education beyond compulsory basic education in order to minimize negative long-term consequences? In the context of this analysis, the question is why parents should not want their children to be streamed into the higher secondary school track?

One possible answer to this question is that, in terms of human capital, educational attainment is an investment into future payoffs and as such is a decision under risk where risk may play a role at the aggregate and the individual level. At the aggregate level, random events such as the recent economic crisis or external effects such as technological or political changes may shift sectoral demand which may affect individuals' unemployment risk but also their rates of returns (Leonardi, 2007). This kind of external "market risk" represents an important risk factor, which however cannot be controlled by the individuals.

At the individual level, and focussing on the school track choice, the decision on education should first of all be based on teachers' and parents' assessment of the child's cognitive

progressive education alternatives such as Waldorf schools or Montessori schools. Although privately organized, these schools are also subject to the curricula of the federal state's Ministry of Education.

6 Reduction to eight years has been agreed upon, but the adjustment has not yet been realized in all federal states.

7 Beyond that, there is evidence for social selectivity at both the initial and later transition stages (cf., for example, Jacob/Tieben, 2009, Glaesser and Cooper, 2010). 
and non-cognitive abilities, proxied by for example exam marks and whether the child is motivated to learn. Exact predictions of a child's future achievements however are not possible so that it is not clear whether both monetary expenditures and non-monetary opportunity costs will pay off. Such unknown probabilities of the individual's achievement - including for example the risk of dropping out from higher secondary schooling - can discourage risk averse individuals to invest in human capital or education already at the outset.

Given a level of a child's abilities that would allow attending the higher secondary school track, we would in sum expect that educational decisions are subject to individuals' risk preferences. As noted above, there however are two possible, contradictory effects. On the one hand, if future returns to education are uncertain, risk averse individuals will avoid such investments and we would therefore expect risk averse parents to be in favor for the lower secondary school track. On the other hand, higher education might be thought of as "safe haven", i.e. as type of insurance, since the positive correlation between educational attainment and labor market outcomes is well-known. Risk averse parents might then less likely want their children enrolled in the lower secondary school track.

While this ambiguity is not satisfactory from a theoretical point of view, we believe that it is the first notion - risk averse individuals shy away from investments with uncertain outcomes - that is the mechanism at work here, even more so since previous evidence yields results in line with this argument.

\section{Previous research}

First, there is substantial evidence that risk attitudes are related to adult individuals' behavior and outcomes including labor market success. Hartog/Ferrer-i Carbonell/Jonker (2002) for example show that women as well as civil servants are more risk averse than their counterparts, but that self-employed are more willing to take risks. Bonin et al. (2007) use data from the German Socio-Economic Panel (SOEP), the data we also use in the analyses below, and show that individuals with low willingness to take risks are more likely to be sorted into occupations with low earnings risk. Pfeifer (2009) also uses SOEP data and finds positive correlations between risk taking attitudes and being employed via temporary agency work, or having a fixed-term contract, between risk taking and the workers' likelihood of changing the employer or quitting their job, and between risk taking and participation in further training. In line with these findings, he shows in another study that more risk averse individuals sort into the public sector (Pfeifer, 2010).

There further is research on the relationship between individuals' risk attitudes and their own educational attainment. In an early study, Weiss (1972) uses data from the $1966 \mathrm{Na}$ tional Register of Scientific and Technical Personnel and provides evidence for a negative impact of risk aversion on human capital investments and on the returns to education. The results of Shaw (1996), which are based on data from the 1983 Survey of Consumer Finances, indicate a positive correlation between risk taking behavior and wage growth as well as hiaher returns to education for less risk averse persons. In contrast. Barsky et al. (1997) describe a u-shaped relationship between risk tolerance and years of education with the peak at 12 years which is in line with the findings of Brown/Ortiz/Taylor (2006) 
who use the U.S. Panel Study of Income Dynamcis (PSID). Belzil/Leonardi (2007) use the Italian Survey of Household Income and Wealth (SHIW) to explain differences in schooling by individual risk heterogeneity. Their results indicate only a small negative effect of risk attitudes on schooling attainment.

In addition, there so far is only one study by Leonardi (2007) that addresses whether parents' risk attitudes play a role for the schooling track decision of their young adult (19-23 years) children. Using 1995 Italian SHIW data, he concludes that differences in risk attitudes are no important determinant of secondary school choice. While this finding is at odds with our expectations, note that his analysis differs from ours inasmuch as he 1) examines the outcomes of individuals in the age range 19-23 whereas we look at younger children, and 2) he uses a risk aversion measures derived from a hypothetical lottery question while we base our analyses on parents' willingness to take risks in their occupational career. As noted above, we believe this to be a more appropriate measure for analyzing the gradient between risk attitudes and investments in human capital.

\section{Data and methods}

Our analyses are based on data from the German Socio-economic Panel Study (SOEP). The SOEP is a representative, annual household panel study that started in 1984 in West Germany with more than 12,000 adult respondents in about 5,900 households. It was extended to former East Germany in 1990 and refreshed with additional samples later on, so that it now consists of more than 20,000 adults. The SOEP is a quite rich database including a wide range of information on the socioeconomic status of both private households and individuals (see Wagner/Frick/Schupp, 2007).

As we are interested in the risk-education gradient for students' initial secondary school track choice ${ }^{8}$ we restrict our sample to adult respondents with children who are 10 to 15 years old. We thus focus on children who have not yet acquired the first possible school leaving certificate and who could then for example be enrolled in further education in order to upgrade. Another reason for the upper age bound is that adolescents quite likely start to act stronger on their own behalf so that we could not be sure whether the track we observe at age 16 or older is the one that, we argue, was first dominated by the parents' expectations and preferences.

As for the child's secondary school track choice, we focus on the three major schooling tracks as outlined above: lower secondary (Hauptschule), intermediate secondary (Realschule) and upper secondary (Gymnasium). Therefore, our dependent variable is a categorical variable with three outcomes:

\footnotetext{
8 We cannot rule out that the observed school track is not the initial choice, but we believe that the potential error is small because of the low mobility across tracks.
} 
$y_{i}= \begin{cases}1, & \text { if the child attends the lower secondary schooling track (Hauptschule) } \\ 2, & \text { if the child attends the intermediate secondary schooling track (Realschule) } \\ 3, & \text { if the child attends the upper secondary schooling track (Gymnasium) }\end{cases}$

Information on individuals' risk attitudes were first surveyed in 2004. In addition to a hypothetical lottery question, the questionnaire includes several items on the respondent's selfreported general and context-specific risk attitudes. General risk attitudes are surveyed asking "How do you see yourself: Are you generally a person who is fully prepared to take risks or do you try to avoid taking risks?", to which answers could be given on a 11-point Likert-type scale from 0 (risk averse) to 10 (fully prepared to take risks). Context-specific risk attitudes are measured as answers to "People can behave differently in different situations. How would you rate your willingness to take risks in the following areas?", where areas mentioned are risk taking while driving, in financial matters, during leisure and sport, in the respondent's occupational career, with his or her health, and his or her faith in other people.

While previous research on the education-risk gradient is based on risk measures derived from lottery questions (see the literature references above), Dohmen et al. (2005) experimentally validate that the self-reported risk measures as surveyed in the SOEP are valid predictors for individuals' risk taking behavior. They further point out that context-specific risk attitudes are good predictors for context-specific behavioral outcomes. Individuals' risk attitude towards health, for example, is a better predictor for their health behavior than the lottery question measure. We therefore base our analyses on the individuals' risk taking willingness in his or her occupational career which we believe to be the more appropriate measure with regard to the gradient between risk and human capital investments. We however run additional analyses using both risk taking willingness in financial matters and the general risk taking attitudes as robustness checks (see below).

Given the ordinal 11-point scale, we could generate up to eleven risk attitude dummies. This however is unhandy for interpretation so that we calculate mean and standard deviation separately by mothers' and fathers' career risk attitudes in order to create the following three risk categories: ${ }^{9}$

\section{A parent is}

- risk averse, if her response value $X$ is smaller than the mean $(\mu)$ minus the standard deviation $(\sigma): X<\mu-\sigma$,

- risk neutral, if $X$ is in a range between mean plus/minus one standard deviation: $\mu$ $\sigma<=X<=\mu+\sigma$,

- risk loving, if $\mathrm{X}$ is larger than the mean plus the standard deviation: $X>\mu+\sigma$.

\footnotetext{
9 Note again that the variable is measured on an ordinal and not on a metric scale. Compared with other approaches, like a more or less arbitrary separation in four or five categories, we prefer using information from the observed distributions.
} 
Since there is evidence that 1) males and females differ in their willingness to take risks (Dohmen et al., 2005) and that 2) mothers are much more involved in their children's schooling activities (Enders-Dragässer/Sellach/Libuda-Köster, 2004; Oesterbacka/Merz/Zick, 2010) which might lead to a bigger influence of particularly mothers' risk attitudes in the tracking decision, we run separate analyses for mothers and fathers. Our final sample consists of 1,207 mother-child observations and of 1,000 father-child observations ${ }^{10}$.

A first impression of the relationship is given in Figure 2 which provides the distribution of children's secondary school track choice by their parents' willingness to take risks in their occupational career. It shows that children of risk loving parents are much more likely enrolled in the upper secondary school track whereas children of risk averse mothers are more likely enrolled in the lower secondary school track.

[Figure 2 about here]

Since these descriptive findings can be confounded by other factors we control for a large range of socio-demographic and -economic characteristics in our regression analyses below. Parents' education clearly is a key determinant of children's secondary school track choice. In line with the structure of the educational system outlined above, we include whether the parent has acquired a lower, intermediate or upper secondary schooling degree, and we further include a dummy on whether the parent's education information is missing. Parents' employment status is another relevant covariate since it relates to the household's budget constraint and might also be related to the time parents can invest in assisting their children for example, in doing homework. The monetary budget constraint is further accounted for by the log of the monthly net equivalence household income. More controls are the child's age, whether the child is a boy, three dummies on the number of children in the family (only child, two siblings, three and more siblings), the parent's age (at birth of the child), and whether the parent has Non-German nationality.

We moreover include the size of the respondents' residence to capture possible differences between rural and non-rural areas in the supply of intermediate and particularly upper secondary schools. As outlined above, the role of teachers' track recommendation after primary school differs in the federal states. We add a dummy for the four federal states (Bavaria, Baden-Württemberg, Saxony, Thuringia), where the recommendation is binding.

Given the categorical character of our dependent variable, we use the multinomial logit estimator which allows for differences in each covariate's marginal effect across categories. ${ }^{11}$ Our baseline model then describes the correlation between the child's secondary school track choice and a vector of covariates $\operatorname{Pr}\left(Y_{i}=j \mid X_{i}\right)$, where $X$ comprises the parent's risk attitude as well as the above noted controls.

In order to capture the relation between the parent's own education and his or her risk attitude, we extend our baseline specification by including terms interacting the respondent's

\footnotetext{
10 See the Appendix for descriptive statistics.

11 We tested whether the independence of irrelevant alternatives (IIA) assumption underlying the multinomial logit model holds and found no evidence to the contrary.
} 
risk attitude and his or her highest educational achievement. To avoid the issues that come along with the calculation of marginal effects in non-linear models that include interaction terms (Ai/Norton, 2003; Greene, 2010), we simulate changes in parents' risk preferences in order to calculate the corresponding conditional predicted probabilities of the child's secondary school track choice: $\operatorname{Pr}\left(Y_{i} \mid\right.$ parent's risk attitude), where parent's risk attitude could be averse or neutral or loving.

Since we are mainly interested in the effects of risk aversion vs. the willingness to take risks, we calculate the following differences:

$\Delta_{L}=\operatorname{Pr}($ lower track / parent is risk averse) $-\operatorname{Pr}$ (lower track / parent is risk loving)

$\Delta_{I}=\operatorname{Pr}$ (intermediate track / parent is risk averse) - Pr(intermediate track / parent is risk loving)

$\Delta_{U}=\operatorname{Pr}($ upper track / parent is risk averse) - Pr(upper track / parent is risk loving)

In addition to our baseline specifications we run the following robustness tests: 1) we employ the individual's score on the risk willingness scale, i.e. we use a quasi-metric measure; 2 ) in order to check sensitivity of the risk measure used, we employ the individual's general risk willingness attitude as well as her risk attitude in financial matters. As a further extension, we are interested in whether there are differences by child gender so that we run separate analyses for mother/father-son/daughter subsamples.

\section{Results}

Table 1 and 2 report average marginal effects (Bartus, 2005) for the baseline model, separately for mothers and fathers, showing the impact of the independent variables on the secondary school choice probabilities. First, and unsurprising, the most influential control variables are parent's education and household income. Having a parent with an upper secondary schooling degree increases the probability of the child being enrolled in the upper secondary schooling track by about 21 percentage points (mothers, Table 1) or almost 24 percentage points (fathers, Table 2), compared to a child whose mother or father achieved an intermediate secondary schooling degree. A complementing picture is found for parents with lower secondary schooling degree, whose children are more likely enrolled in the lower secondary school track. That is, we find evidence for a strong education transmission from parents to children which is in line with previous research on intergenerational education mobility (Heineck/Riphahn, 2009). Children in higher income households also have greater chances for enrollment in the upper secondary school track. Moreover, living in a federal state where teachers' recommendation is binding is associated with higher probabilities of enrollment in the lower secondary track and, complementary to this, with lower probabilities of enrollment in the upper secondary track. ${ }^{12}$

Regarding our central interest, the estimates first suggest for no impact of a high parental willingness to take risks on children's secondary school track choice, compared to an av-

\footnotetext{
12 Intuitively, it is plausible to assume that parents avoid the costs that come along with challenging a binding recommendation.
} 
erage risk taking attitude. Having a risk averse mother, however, is correlated with a 9 percentage point decrease in the probability of the child being enrolled in the upper secondary school track and 6 percentage points increase for enrollment in the lower secondary school track. This may seem a modest effect but it comes close to the association between binding teachers' recommendation and children's secondary school enrollment. The overall pattern also indicates a substantial gradient: conditional on mothers' risk attitude, the predicted probabilities imply that the higher a mother's risk willingness, the more likely is enrollment in upper secondary school and the less likely is enrollment in the lower secondary school track (cf. the lower panel in Table 1).

[Table 1 about here]

While this finding is in line with the above mentioned notion that education is looked at as a risky investment from which risk averse individuals shy away, we find a somewhat different pattern for fathers. In particular, the estimates indicate a small negative weakly statistically significant association between father's risk aversion and the child's enrollment in the lower secondary school track (Table 2, column 1). This is at odds with our preferred hypothesis but in line with the "safe haven" notion. Yet, the negative sign of the average marginal effect of father's risk aversion on the child's enrollment in the upper schooling track may indicate that fathers opt for a middle way. In addition, calculating predicted probabilities conditional on fathers' risk willingness (cf. the lower panel in Table 2), we find only little differences in children's secondary school track choice as fathers' attitude towards risk in their occupational career varies.

[Table 2 about here]

As a next step, we extend our baseline model and include interaction terms of parental risk attitudes and education in order to control for the relation between parent's own education and her or his risk attitude. Similar to the conditional predicted probabilities above, we calculate differences in the predicted school enrollment outcomes after varying parental risk attitudes, while all other covariates, including parental education, are kept at the observed values. The results of these simulation exercises are provided in Table 3 .

[Table 3 about here]

They reinforce the findings of our baseline models inasmuch as there is no convincing evidence for a link between fathers' risk attitude and their child's school track but a striking gradient between mothers' risk attitude and their child's secondary school track enrollment. In particular, the difference in predicted probabilities of enrollment in the lower track amounts to about 6.9 percentage points conditional on the mother being either risk averse 
or risk loving. That is, having a risk averse mother rather than a risk loving mother significantly increases the child's probability of being enrolled in the lowest secondary school track. The impact of maternal risk attitudes is even stronger looking at the upper secondary school track: There is a difference of some 10 percentage points in predicted probabilities meaning that the child of a risk loving mother is much more likely enrolled in the directly university-qualifying schooling track.

\section{Robustness}

\section{Using the metric scale}

In our baseline models above, we use categorical risk variables as derived from the underlying risk attitude distributions. In order to examine the stability of our first findings, we now employ the score on the Likert-type scale itself. The results in Table 4 mainly show similar patterns as compared to the estimations that include risk categories. An increase in fathers' risk willingness by one unit is not statistically associated to children's secondary school track anymore. The pattern however is the same as found above inasmuch as the average marginal effects hint towards a, say, u-shaped gradient. In line with our baseline model findings, there again is evidence for a monotonic relation between mother's occupational career risk willingness and her child's secondary school track: a one unit increase in risk willingness decreases the predicted probabilities of enrollment in the lower track and increases enrollment in the upper track by one percentage point respectively.

\section{[Table 4 about here]}

Figure 3 features this result again showing that, irrespective of the mother having either a lower or an upper secondary schooling degree, the child's probabilities of being enrolled in the upper secondary schooling track increases by roughly ten percentage points increasing the maternal risk taking willingness from 0 to 10. Complementing this, an increase in risk taking willingness over the whole range decreases lower secondary school enrollment also by about ten percentage points.

[Figure 3 about here]

General risk taking and risk attitudes towards financial matters

As outlined above, our analysis differs from the existing studies (for example, Belzil/Leonardi, 2007; Leonardi, 2007) inasmuch as we do not employ individuals' risk aversion derived from hypothetical lottery questions, but respondents' self-reported risk attitudes towards occupational career. Again, in line with Dohmen et al. (2005) who point out that using hypothetical lottery scenarios can mislead when predicting context specific behavior ( $p$. 30), we argue that this is better suited in order to capture the relation between risk taking attitudes and human capital investments. We however run further robustness checks to 
accommodate prior research by using 1) individuals' general risk taking attitudes, which is a better overall risk behavior predictor than a lottery measure (Dohmen et al., 2005), and 2) their risk taking willingness in financial matters.

Compared to the findings from our preferred model, the results for individuals' general risk taking attitudes imply slightly different findings for mothers but similar ones for fathers: while mothers' risk aversion estimates above suggest for a monotonic inverse gradient, the results now indicate no statistical association. There however is an almost 5 percentage points decrease for risk loving mothers in the probability of their child's enrollment in the lower secondary school track (Table 5, column 1) which complements the prior finding. Similar to the results that employ risk taking in occupational career, we find a 2.5 percentage point decrease for risk averse fathers that the child is enrolled in the lower secondary track. This again hints towards the "safe haven" hypothesis, even more so since we further find a ten percentage point increase in the predicted probability that the child is streamed into the intermediate secondary schooling track. The negative sign of the average marginal effect on the enrollment in the upper secondary track would again suggest for shying away from this option, yet this is not statistically significant.

\section{[Table 5 about here]}

The results for risk taking in financial matters (Table 6) are almost the same for mothers as the results for the general risk taking attitudes. There, first, is an about 5 percentage point decrease in the predicted lower secondary track enrollment for risk loving mothers but otherwise no convincing statistical association. Again in line with the findings for fathers so far, there is no evidence for risk loving attitudes on children's secondary school track choice. The results however once more indicate that risk averse fathers opt for the average inasmuch as we find a 9 percentage point increase in the probability of the child being enrolled in the intermediate track and an 11 point decrease of enrollment in the upper secondary track.

\section{[Table 6 about here]}

For both robustness tests, i.e. employing general risk attitudes and risk taking in financial matters, we also carried out simulation exercises similar to the ones in our baseline model. We do not present these findings since the differences in the predicted probabilities are mainly not statistically different from zero. There are two exceptions: similar to the findings for mothers above, there is a ten percentage points difference in the lower track enrollment probability for a mother who is either risk averse or risk loving in financial matters with a higher probability found for the risk averse mother. We, second, find an eight percentage points increase the child's probability of being enrolled in the upper secondary track once we vary fathers' risk attitude from aversion to risk taking willingness also in financial 
matters. ${ }^{13}$

\section{Differences by child gender?}

Recent research further suggests for gender-specific intergenerational education transmission, i.e. that fathers' education is more important for the educational achievement of sons and, similarly, mother's education is more relevant for daughters' educational outcomes (e.g. Dearden/Machin/Reed, 1997; Heineck/Riphahn, 2009; Kleinịans, 2010).

Given this evidence and the observation that risk taking willingness differs between males and females (Dohmen et al., 2005), we extend our analysis and separate the samples by the child's sex in order to examine whether parent's risk attitudes affect boys' or girls' secondary school enrollment differently (Table 7). Our results highlight two findings: First, parental risk attitudes play a larger role for daughters than for sons, inasmuch as none of the average marginal effects on the outcomes of boys is statistically different from zero, irrespective of whether we look at the mother-son or father-son gradient. Second, we again find hints towards different underlying mechanisms for father and mothers. In line with the findings of our baseline model above, having a risk averse mother is associated with an increase of about 8 percentage points in the daughter's probability of being enrolled in the lower secondary track, the negative effect of risk aversion on the child's enrollment in the upper tracks however just misses the 10\%-significance threshold (which quite likely is because of the small subsample size). For fathers, we again find that risk aversion is negatively associated with enrollment, but that risk loving substantially decreases the boy's chances of being enrolled in the intermediate secondary track and substantially increases his probability of being enrolled in the upper track, with changes of almost 14 and 17 percentage points respectively.

As a final exercise, we generate a joint indicator for parental attitudes, built up on the distribution of the average of mothers' and fathers' risk attitude scores. The findings represent a mixture of our results above: In line with the evidence for fathers, joint parental risk aversion decreases the probability of child's enrollment in the lower secondary track, and full risk taking willingness increases the enrollment probability in the upper secondary school track which is in line with the evidence for the father-daughter gradient. However, since the sample size does not allow to further disentangle the 'intra-parental' risk composition, which would be a more fruitful approach, we do not want to overemphasize this additional, complementary finding.

[Table 7 about here]

\section{Summary and conclusions}

There is growing research addressing the effects of individuals' cognitive and non-cognitive skills on different labor market outcomes (see Borghans et al., 2008, for an overview).

\footnotetext{
${ }^{13}$ Full details are available upon request.
} 
The role of individuals' risk attitudes has also attracted scholarly effort within this strand of research (ibid., p. 1002 f.) but has largely concentrated on issues such as portfolio choice, occupational choice, or earnings. Yet, as future outcomes of individuals' educational choices are uncertain and might thus represent risky investments, it is plausible to assume that individual's risk taking willingness may have an impact on educational choices of the individual herself but also that her risk attitude affects the educational path of her children.

Theoretically, it is however not that clear a priori whether risk averse individuals would try to avoid educational investments as education might also serve as "safe haven", i.e. would have an insurance type character. Our analysis sheds light on this issue and we examine whether parental risk attitudes are associated to the secondary school track choice of their children and which of the two mechanisms is at work.

We add to an almost non-existent literature, with the study of Leonardi (2007) as the only prior research on the parent-children gradient. We explore the German case which is as interesting and possibly even more relevant because of the institutional setting that streams children at age ten, i.e. very early, into different secondary school tracks. Upward mobility between tracks is low so that the initial choice has a strong predetermining character.

Our results imply the following: 1) everything else constant, risk averse mothers are more likely to have their child enrolled in the lower secondary schooling track, and particularly so if the child is a girl, and less likely enrolled in the upper secondary track. With substantial changes in the predicted probabilities (6 and 10 percentage points respectively), this supports the notion that education is looked at as risky investment. 2) In contrast, the findings for father are not as convincing and consistent as for mothers and are more in line with the "safe haven" argument inasmuch as the children of risk averse fathers are less likely enrolled in the lower secondary school track. We again find a stronger effect for daughters which is further complemented by the evidence that daughters of risk loving fathers are much more likely enrolled in the upper secondary track which directly qualifies for entrance in universities.

Social mobility is strongly determined by patterns of intergenerational transmission mechanisms. Our findings show that there are factors other than parental education or income, that affect one of the most critical decisions for children's later life course. As such, our findings reinforce the recent evidence in economics that non-cognitive skills do matter for labor market and educational outcomes and extend it inasmuch as such skills play a role, not only of the individual itself but also for her or his children. Given that our analysis is only the second attempt to explore this specific question it might be too early to deduce policy implications on the individual level. Yet, it might either way be useful to consider relaxing the requirements for particularly upward track mobility so that a possibly wrong initial choice based on, amongst other things, parental risk taking attitudes could be more easily reversed. 


\section{Tables}

Table 1: Children's secondary school track choice: Baseline specification for mothers

\begin{tabular}{|c|c|c|c|}
\hline & $\operatorname{Pr}(\mathrm{y}=$ lower sec. $)$ & $\operatorname{Pr}(\mathrm{y}=$ secondary $)$ & $\operatorname{Pr}(y=$ upper sec. $)$ \\
\hline \multicolumn{4}{|l|}{ Average Marginal Effects } \\
\hline Risk averse (Career) & $\begin{array}{c}0.059^{* *} \\
(0.027)\end{array}$ & $\begin{array}{c}0.032 \\
(0.042)\end{array}$ & $\begin{array}{c}-0.091^{* *} \\
(0.042)\end{array}$ \\
\hline Risk loving (Career) & $\begin{array}{r}-0.017 \\
(0.021)\end{array}$ & $\begin{array}{c}0.008 \\
(0.040)\end{array}$ & $\begin{array}{c}0.009 \\
(0.040)\end{array}$ \\
\hline Mother's education: lower sec. & $\begin{array}{l}0.212^{* * *} \\
(0.037)\end{array}$ & $\begin{array}{c}-0.076^{* *} \\
(0.035)\end{array}$ & $\begin{array}{c}-0.136^{* * *} \\
(0.037)\end{array}$ \\
\hline Mother's education: upper sec. & $\begin{array}{c}-0.051^{* * *} \\
(0.019)\end{array}$ & $\begin{array}{c}-0.163^{* * *} \\
(0.031)\end{array}$ & $\begin{array}{l}0.214^{* * *} \\
(0.034)\end{array}$ \\
\hline Mother's education: missing & $\begin{array}{l}0.139^{* * *} \\
(0.050)\end{array}$ & $\begin{array}{c}-0.088 \\
(0.055)\end{array}$ & $\begin{array}{c}-0.052 \\
(0.063)\end{array}$ \\
\hline Mother's age at birth & $\begin{array}{c}-0.008^{* * *} \\
(0.002)\end{array}$ & $\begin{array}{c}-0.005 \\
(0.003)\end{array}$ & $\begin{array}{l}0.012^{* * *} \\
(0.003)\end{array}$ \\
\hline Mother: Migrant & $\begin{array}{c}-0.006 \\
(0.024)\end{array}$ & $\begin{array}{c}0.026 \\
(0.055)\end{array}$ & $\begin{array}{c}-0.020 \\
(0.057)\end{array}$ \\
\hline Mother's employment: Unemployed & $\begin{array}{c}-0.023 \\
(0.020)\end{array}$ & $\begin{array}{c}0.018 \\
(0.045)\end{array}$ & $\begin{array}{c}0.005 \\
(0.046)\end{array}$ \\
\hline Mother's employment: Part-time & $\begin{array}{r}-0.032^{*} \\
(0.017)\end{array}$ & $\begin{array}{c}0.007 \\
(0.040)\end{array}$ & $\begin{array}{c}0.024 \\
(0.040)\end{array}$ \\
\hline Male child & $\begin{array}{l}0.049^{* *} \\
(0.021)\end{array}$ & $\begin{array}{r}-0.004 \\
(0.029)\end{array}$ & $\begin{array}{r}-0.045 \\
(0.030)\end{array}$ \\
\hline Child's age & $\begin{array}{c}-0.040^{* * *} \\
(0.008)\end{array}$ & $\begin{array}{c}0.017^{*} \\
(0.010)\end{array}$ & $\begin{array}{l}0.023^{* *} \\
(0.009)\end{array}$ \\
\hline Number of siblings: 0 & $\begin{array}{c}0.023 \\
(0.028)\end{array}$ & $\begin{array}{c}0.006 \\
(0.046)\end{array}$ & $\begin{array}{c}-0.029 \\
(0.045)\end{array}$ \\
\hline Number of siblings: 2 & $\begin{array}{c}-0.009 \\
(0.019)\end{array}$ & $\begin{array}{c}0.042 \\
(0.038)\end{array}$ & $\begin{array}{c}-0.033 \\
(0.038)\end{array}$ \\
\hline Number of siblings: 3 or more & $\begin{array}{c}0.047 \\
(0.030)\end{array}$ & $\begin{array}{c}0.021 \\
(0.046)\end{array}$ & $\begin{array}{c}-0.067 \\
(0.047)\end{array}$ \\
\hline Equiv. net $\mathrm{HH}$-income & $\begin{array}{l}-0.156^{* * *} \\
(0.028)\end{array}$ & $\begin{array}{l}-0.090^{* * *} \\
(0.033)\end{array}$ & $\begin{array}{l}0.246^{* * *} \\
(0.030)\end{array}$ \\
\hline Federal state with binding recommendation & $\begin{array}{l}0.072^{* * *} \\
(0.023)\end{array}$ & $\begin{array}{c}0.011 \\
(0.031) \\
\end{array}$ & $\begin{array}{c}-0.082^{* * *} \\
(0.030)\end{array}$ \\
\hline Log likelihood & & -1050.930 & \\
\hline Predicted Probabilities & & & \\
\hline $\operatorname{Pr}(. . . /$ mother's risk attitude $=$ averse $)$ & $\begin{array}{l}0.313^{* * *} \\
(0.027)\end{array}$ & $\begin{array}{l}0.332^{* * *} \\
(0.033)\end{array}$ & $\begin{array}{l}0.355^{* * *} \\
(0.031)\end{array}$ \\
\hline $\operatorname{Pr}(. . . /$ mother's risk attitude $=$ neutral $)$ & $\begin{array}{l}0.240^{* * *} \\
(0.015)\end{array}$ & $\begin{array}{l}0.325^{* * *} \\
(0.017)\end{array}$ & $\begin{array}{l}0.434^{* * *} \\
(0.017)\end{array}$ \\
\hline $\operatorname{Pr}(\ldots /$ mother's risk attitude $=$ loving $)$ & $\begin{array}{l}0.216^{* * *} \\
(0.031)\end{array}$ & $\begin{array}{l}0.339^{* * *} \\
(0.035)\end{array}$ & $\begin{array}{l}0.445^{* * *} \\
(0.033)\end{array}$ \\
\hline
\end{tabular}

Notes: Multinomial Logit estimation, average marginal effects. $\mathrm{N}=1,207$ mother-child observations. The estimation further controls for size of residence fixed effects. Predictions are generated as the average of all individual predicted probabilities (calculated with the individually observed values of the covariates), after mother's risk attitude variable is modified. Standard errors in parentheses. ${ }^{* \star * * *}$ significant at $1 \%$ $5 \% 10 \%$.

Source: SOEP, 2004. Authors' own calculations. 
Table 2: Children's secondary school track choice: Baseline specification for fathers

\begin{tabular}{|c|c|c|c|}
\hline & $\operatorname{Pr}(y=$ lower sec. $)$ & $\operatorname{Pr}(\mathrm{y}=$ secondary $)$ & $\operatorname{Pr}(y=$ upper sec. $)$ \\
\hline \multicolumn{4}{|l|}{ Average Marginal Effects } \\
\hline Risk averse (Career) & $\begin{array}{r}-0.025^{*} \\
(0.015)\end{array}$ & $\begin{array}{c}0.031 \\
(0.051)\end{array}$ & $\begin{array}{r}-0.006 \\
(0.052)\end{array}$ \\
\hline Risk loving (Career) & $\begin{array}{r}-0.020 \\
(0.014)\end{array}$ & $\begin{array}{r}-0.026 \\
(0.042)\end{array}$ & $\begin{array}{c}0.047 \\
(0.044)\end{array}$ \\
\hline Father's education: lower & $\begin{array}{l}0.143^{* * *} \\
(0.037)\end{array}$ & $\begin{array}{c}0.014 \\
(0.043)\end{array}$ & $\begin{array}{c}-0.157^{* * *} \\
(0.041)\end{array}$ \\
\hline Father's education: upper sec. & $\begin{array}{c}-0.046^{* * *} \\
(0.013)\end{array}$ & $\begin{array}{c}-0.190^{* * *} \\
(0.035)\end{array}$ & $\begin{array}{l}0.236^{* * *} \\
(0.038)\end{array}$ \\
\hline Father's education: missing & $\begin{array}{c}0.067 \\
(0.044)\end{array}$ & $\begin{array}{c}-0.170^{* * *} \\
(0.055)\end{array}$ & $\begin{array}{c}0.103 \\
(0.071)\end{array}$ \\
\hline Father's age at birth & $\begin{array}{c}-0.003 \\
(0.002)\end{array}$ & $\begin{array}{c}-0.002 \\
(0.003)\end{array}$ & $\begin{array}{l}0.005^{* *} \\
(0.003)\end{array}$ \\
\hline Father: Migrant & $\begin{array}{c}0.046 \\
(0.029)\end{array}$ & $\begin{array}{l}0.125^{* *} \\
(0.059)\end{array}$ & $\begin{array}{c}-0.171^{* * *} \\
(0.058)\end{array}$ \\
\hline Father's employment: Unemployed & $\begin{array}{l}0.087^{* *} \\
(0.039)\end{array}$ & $\begin{array}{c}0.007 \\
(0.064)\end{array}$ & $\begin{array}{c}-0.094 \\
(0.069)\end{array}$ \\
\hline Father's employment: Part-time & $\begin{array}{c}0.112 \\
(0.073)\end{array}$ & $\begin{array}{c}0.004 \\
(0.107)\end{array}$ & $\begin{array}{c}-0.115 \\
(0.107)\end{array}$ \\
\hline Male child & $\begin{array}{c}0.026 \\
(0.017)\end{array}$ & $\begin{array}{c}-0.047 \\
(0.033)\end{array}$ & $\begin{array}{c}0.021 \\
(0.035)\end{array}$ \\
\hline Child's age & $\begin{array}{c}-0.039^{* * *} \\
(0.008)\end{array}$ & $\begin{array}{l}0.023^{* *} \\
(0.010)\end{array}$ & $\begin{array}{c}0.016^{*} \\
(0.010)\end{array}$ \\
\hline Number of siblings: 0 & $\begin{array}{c}0.004 \\
(0.025)\end{array}$ & $\begin{array}{c}-0.000 \\
(0.056)\end{array}$ & $\begin{array}{c}-0.004 \\
(0.057)\end{array}$ \\
\hline Number of siblings: 2 & $\begin{array}{c}0.009 \\
(0.019)\end{array}$ & $\begin{array}{c}0.069 \\
(0.044)\end{array}$ & $\begin{array}{r}-0.078^{*} \\
(0.044)\end{array}$ \\
\hline Number of siblings: 3 or more & $\begin{array}{c}0.048^{*} \\
(0.028)\end{array}$ & $\begin{array}{c}0.056 \\
(0.052)\end{array}$ & $\begin{array}{c}-0.104^{* *} \\
(0.052)\end{array}$ \\
\hline Equiv. net $\mathrm{HH}$-income & $\begin{array}{c}-0.082^{* *} \\
(0.035)\end{array}$ & $\begin{array}{c}-0.103^{* *} \\
(0.041)\end{array}$ & $\begin{array}{l}0.185^{* * *} \\
(0.037)\end{array}$ \\
\hline Federal state with binding recommendation & $\begin{array}{l}0.057^{* * *} \\
(0.022)\end{array}$ & $\begin{array}{c}0.002 \\
(0.035) \\
\end{array}$ & $\begin{array}{c}-0.059 \\
(0.036)\end{array}$ \\
\hline Log likelihood & & -857.707 & \\
\hline Predicted Probabilities & & & \\
\hline $\operatorname{Pr}(. . . /$ father's risk attitude $=$ averse $)$ & $\begin{array}{l}0.193^{* * *} \\
(0.029)\end{array}$ & $\begin{array}{l}0.359^{* * *} \\
(0.037)\end{array}$ & $\begin{array}{l}0.449^{* * *} \\
(0.036)\end{array}$ \\
\hline $\operatorname{Pr}(\ldots /$ father's risk attitude $=$ neutral $)$ & $\begin{array}{l}0.243^{* * *} \\
(0.017)\end{array}$ & $\begin{array}{l}0.315^{* * *} \\
(0.019)\end{array}$ & $\begin{array}{l}0.442^{* * *} \\
(0.019)\end{array}$ \\
\hline $\operatorname{Pr}(. . . /$ father's risk attitude $=$ loving $)$ & $\begin{array}{l}0.206^{* * *} \\
(0.029)\end{array}$ & $\begin{array}{l}0.310^{* * *} \\
(0.031)\end{array}$ & $\begin{array}{l}0.484^{* * *} \\
(0.030)\end{array}$ \\
\hline
\end{tabular}

Notes: Multinomial Logit estimation, average marginal effects. $\mathrm{N}=1,000$ father-child observations. The estimation further controls for size of residence fixed effects. Predictions are generated as the average of all individual predicted probabilities (calculated with the individually observed values of the covariates), after father's risk attitude variable is modified. Standard errors in parentheses. ${ }^{* * * * *}$ * significant at $1 \% 5 \%$ $10 \%$.

Source: SOEP, 2004. Authors' own calculations. 
Table 3: Predicted Probabilities, Simulation results: Extended specification

\begin{tabular}{lccc}
\hline & \multicolumn{3}{c}{ Predicted school track } \\
\cline { 2 - 4 } Mother's risk attitude (Career) & lower sec. & secondary & upper sec. \\
\hline $\mathrm{P}(\ldots \mid$ mother = risk averse (career), IA $)$ & 0.2760 & 0.3576 & 0.3665 \\
$\mathrm{P}(\ldots \mid$ mother $=$ risk neutral (career), IA $)$ & 0.2387 & 0.3274 & 0.4340 \\
$\mathrm{P}(\ldots \mid$ mother = risk loving (career), IA $)$ & 0.2074 & 0.3217 & 0.4709 \\
\hline$\Delta$ averse-loving & $0.0685^{*}$ & 0.0358 & $-0.1044^{* *}$ \\
& $(0.0409)$ & $(0.0515)$ & $(0.0471)$ \\
\hline \hline \multirow{2}{*}{ Father's risk attitude (Career) } & lower sec. & secondary & upper sec. \\
\hline $\mathrm{P}(\ldots \mid$ father $=$ risk averse, IA $)$ & 0.1903 & 0.3667 & 0.4430 \\
$\mathrm{P}(\ldots \mid$ father $=$ risk neutral, IA $)$ & 0.2423 & 0.3159 & 0.4418 \\
$\mathrm{P}(\ldots \mid$ father $=$ risk loving, IA $)$ & 0.2104 & 0.3113 & 0.4784 \\
\hline$\Delta$ averse-loving & -0.0200 & 0.0554 & -0.0354 \\
& $(0.0410)$ & $(0.0494)$ & $(0.0451)$ \\
\hline
\end{tabular}

Notes: $\mathrm{N}=1,207(1,000)$ mother-(father-)child observations. Standard errors (in parentheses) are obtained via bootstrap with 500 repeated draws. ${ }^{* * * * *}$ significant at $1 \% 5 \% 10 \%$.

Source: SOEP, 2004. Authors' own calculations. 
Table 4: Children's secondary school track choice: Estimates using parental risk attitude as metric variable.

\begin{tabular}{lccc}
\hline & $\operatorname{Pr}(\mathrm{y}=$ lower sec. $)$ & $\operatorname{Pr}(\mathrm{y}=$ secondary $)$ & $\operatorname{Pr}(\mathrm{y}=$ =upper sec. $)$ \\
\hline Average Marginal Effects & & & \\
\hline Mother's risk willingness (Career) & $-0.010^{* *}$ & -0.000 & $0.010^{*}$ \\
& $(0.005)$ & $(0.006)$ & $(0.005)$ \\
\hline Father's risk willingness (Career) & 0.001 & -0.009 & 0.008 \\
& $(0.005)$ & $(0.006)$ & $(0.006)$ \\
\hline
\end{tabular}

Notes: Multinomial logit estimation, average marginal effects. $N=1,207(1,000)$ mother-(father-)child observations. The estimations are separately estimated for the mother-child and father-child sample and are based on the baseline specification including the same set of control variables. Risk willingness is used as a metric variable, where "0" indicates no willingness to take risk and "10" full willingness to take risks. Standard errors in parentheses. ${ }^{* * * * *}$ significant at $1 \% 5 \% 10 \%$.

Source: SOEP, 2004. Authors' own calculations. 
Table 5: Children's secondary school track choice: Estimates using general risk taking attitudes

\begin{tabular}{lccc}
\hline & $\operatorname{Pr}(\mathrm{y}=$ lower sec. $)$ & $\operatorname{Pr}(\mathrm{y}=$ secondary $)$ & $\operatorname{Pr}(\mathrm{y}=$ upper sec. $)$ \\
\hline Average Marginal Effects & & & \\
\hline Mother: Risk averse (General) & -0.007 & 0.016 & -0.009 \\
& $(0.024)$ & $(0.044)$ & $(0.045)$ \\
Mother: Risk loving (General) & $-0.046^{* *}$ & 0.071 & -0.025 \\
& $(0.022)$ & $(0.044)$ & $(0.044)$ \\
\hline Father: Risk averse (General) & $-0.025^{*}$ & $0.098^{*}$ & -0.073 \\
& $(0.014)$ & $(0.053)$ & $(0.053)$ \\
Father: Risk loving (General) & -0.024 & 0.048 & -0.024 \\
& $(0.016)$ & $(0.055)$ & $(0.056)$ \\
\hline
\end{tabular}

Notes: Multinomial Logit estimation, average marginal effects. $\mathrm{N}=1,249(1,008)$ mother-(father-)child observations. The estimations are separately estimated for the mother-child and father-child sample and are based on the baseline specification including the same set of control variables. Standard errors in parentheses. ${ }^{* * * * *}$ significant at $1 \% 5 \% 10 \%$.

Source: SOEP, 2004. Authors' own calculations. 
Table 6: Children's secondary school track choice: Multinomial Logit estimates using risk attitudes towards financial assets

\begin{tabular}{lccc}
\hline & $\operatorname{Pr}(\mathrm{y}=$ lower sec. $)$ & $\operatorname{Pr}(\mathrm{y}=$ secondary $)$ & $\operatorname{Pr}(\mathrm{y}=$ upper sec. \\
\hline Average Marginal Effects & & & \\
\hline Mother: Risk averse (Finance) & 0.022 & 0.034 & -0.055 \\
& $(0.022)$ & $(0.035)$ & $(0.035)$ \\
Mother: Risk loving (Finance) & $-0.056^{* * *}$ & 0.044 & 0.012 \\
& $(0.018)$ & $(0.040)$ & $(0.040)$ \\
\hline Father: Risk averse (Finance) & 0.017 & $0.093^{*}$ & $-0.110^{* *}$ \\
& $(0.019)$ & $(0.051)$ & $(0.053)$ \\
Father: Risk loving (Finance) & -0.015 & -0.004 & 0.019 \\
& $(0.015)$ & $(0.045)$ & $(0.046)$ \\
\hline
\end{tabular}

Notes: Multinomial Logit estimation, average marginal effects. $\mathrm{N}=1,249(1,000)$ mother-(father-)child observations. The estimations are separately estimated for the mother-child and father-child sample and are based on the baseline specification including the same set of controls variables. Standard errors in parentheses. ${ }^{* * * * *}$ significant at $1 \% 5 \% 10 \%$.

Source: SOEP, 2004. Authors' own calculations. 
Table 7: Child's secondary school track: Estimates by child's gender

\begin{tabular}{lccc}
\hline & \multicolumn{3}{c}{ Average Marginal Effects } \\
\hline Mother-daughter (N=568) & $\operatorname{Pr}(\mathrm{y}=$ lower sec. $)$ & $\operatorname{Pr}(\mathrm{y}=$ secondary $)$ & $\operatorname{Pr}(\mathrm{y}=$ upper sec. $)$ \\
\hline Risk averse (Career) & $0.085^{* *}$ & 0.011 & -0.096 \\
& $(0.040)$ & $(0.058)$ & $(0.059)$ \\
Risk loving (Career) & 0.018 & -0.016 & -0.002 \\
& $(0.036)$ & $(0.059)$ & $(0.061)$ \\
\hline \hline Mother-son (N=639) & $\operatorname{Pr}(\mathrm{y}=$ lower sec.) & $\operatorname{Pr}(\mathrm{y}=$ secondary) & $\operatorname{Pr}(\mathrm{y}=$ upper sec. $)$ \\
\hline Risk averse (Career) & 0.051 & 0.032 & -0.083 \\
& $(0.045)$ & $(0.059)$ & $(0.055)$ \\
Risk loving (Career) & -0.049 & 0.031 & 0.018 \\
& $(0.036)$ & $(0.055)$ & $(0.053)$ \\
\hline \hline Father-daughter (N=475) & $\operatorname{Pr}(\mathrm{y}=$ lower sec.) & $\operatorname{Pr}(\mathrm{y}=$ secondary $)$ & $\operatorname{Pr}(\mathrm{y}=$ upper sec. $)$ \\
\hline Risk averse (Career) & $-0.052^{* *}$ & 0.024 & 0.028 \\
& $(0.022)$ & $(0.072)$ & $(0.076)$ \\
Risk loving (Career) & -0.035 & $-0.136^{* *}$ & $0.171^{* * *}$ \\
& $(0.027)$ & $(0.056)$ & $(0.062)$ \\
\hline \hline Father-son (N=525) & $\operatorname{Pr}(\mathrm{y}=$ lower sec.) & $\operatorname{Pr}(\mathrm{y}=$ secondary) & $\operatorname{Pr}(\mathrm{y}=$ upper sec.) \\
\hline Risk averse (Career) & -0.005 & 0.001 & 0.003 \\
& $(0.030)$ & $(0.068)$ & $(0.071)$ \\
Risk loving (Career) & -0.020 & 0.059 & -0.039 \\
& $(0.024)$ & $(0.058)$ & $(0.059)$ \\
\hline
\end{tabular}

Notes: Multinomial Logit estimation, average marginal effects. The estimations are separately estimated for the four samples and are based on the baseline specification including the same set of control variables. Standard errors in parentheses. ${ }^{* * * * * *}$ significant at $1 \% 5 \% 10 \%$.

Source: SOEP, 2004. Authors' own calculations. 


\section{Figures}

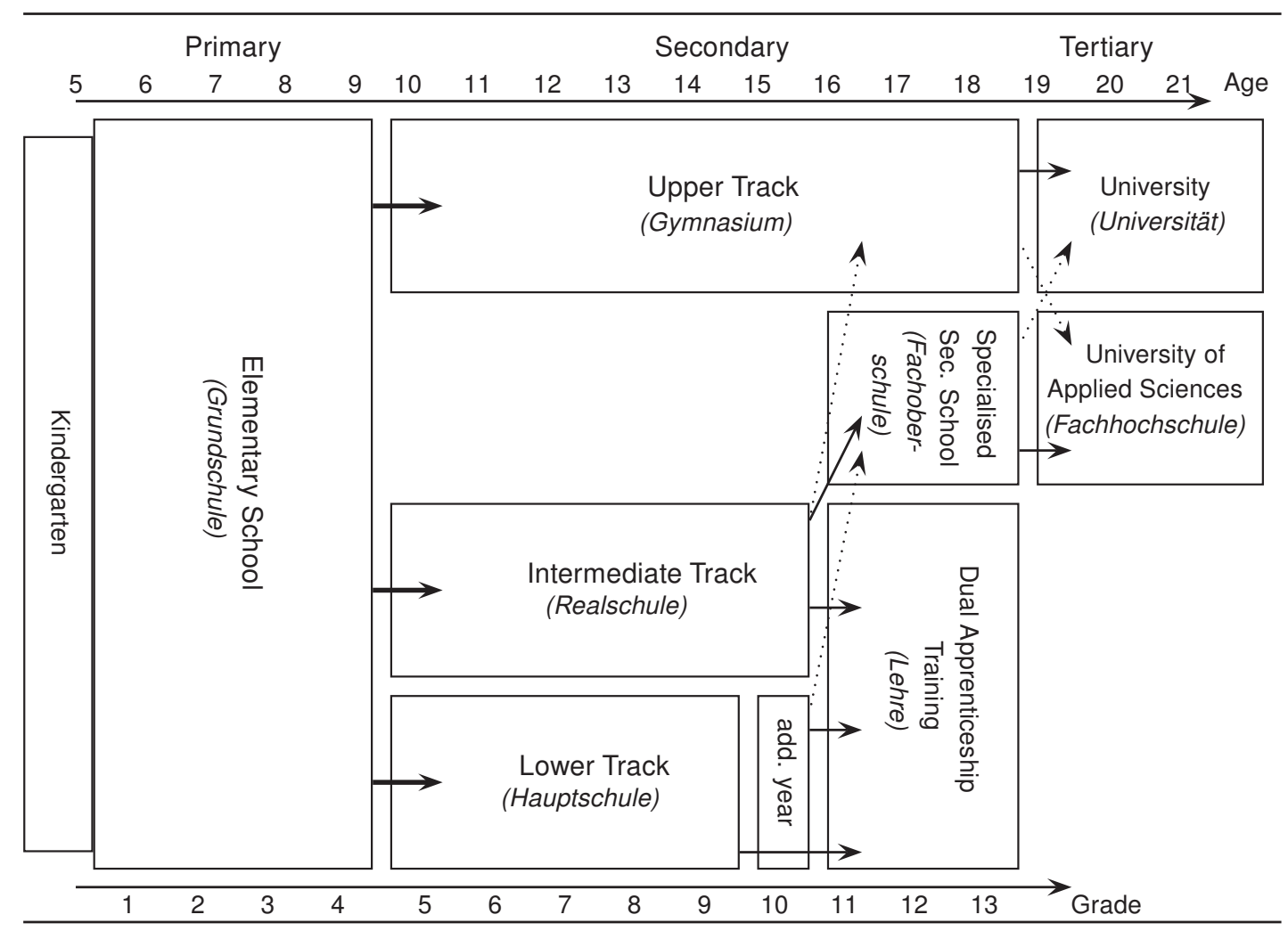

Figure 1: Simplified illustration of the German school system

Note: The German educational system is structured into three tracks (primary, secondary and tertiary). The bold arrows specify the typical paths. The dashed arrows describe transitions which are less common. Other school types (not shown) include comprehensive schools, special schools and some few other, mainly private progressive education alternatives such as Waldorf schools or Montessori schools. In some federal states, students with a lower secondary school degree can achieve the intermediate school degree (Mittlere Reife) within one additional year. Specialised secondary schools (Fachoberschule) offer an upper school degree that, mainly qualifies for entrance in universities of applied sciences. 


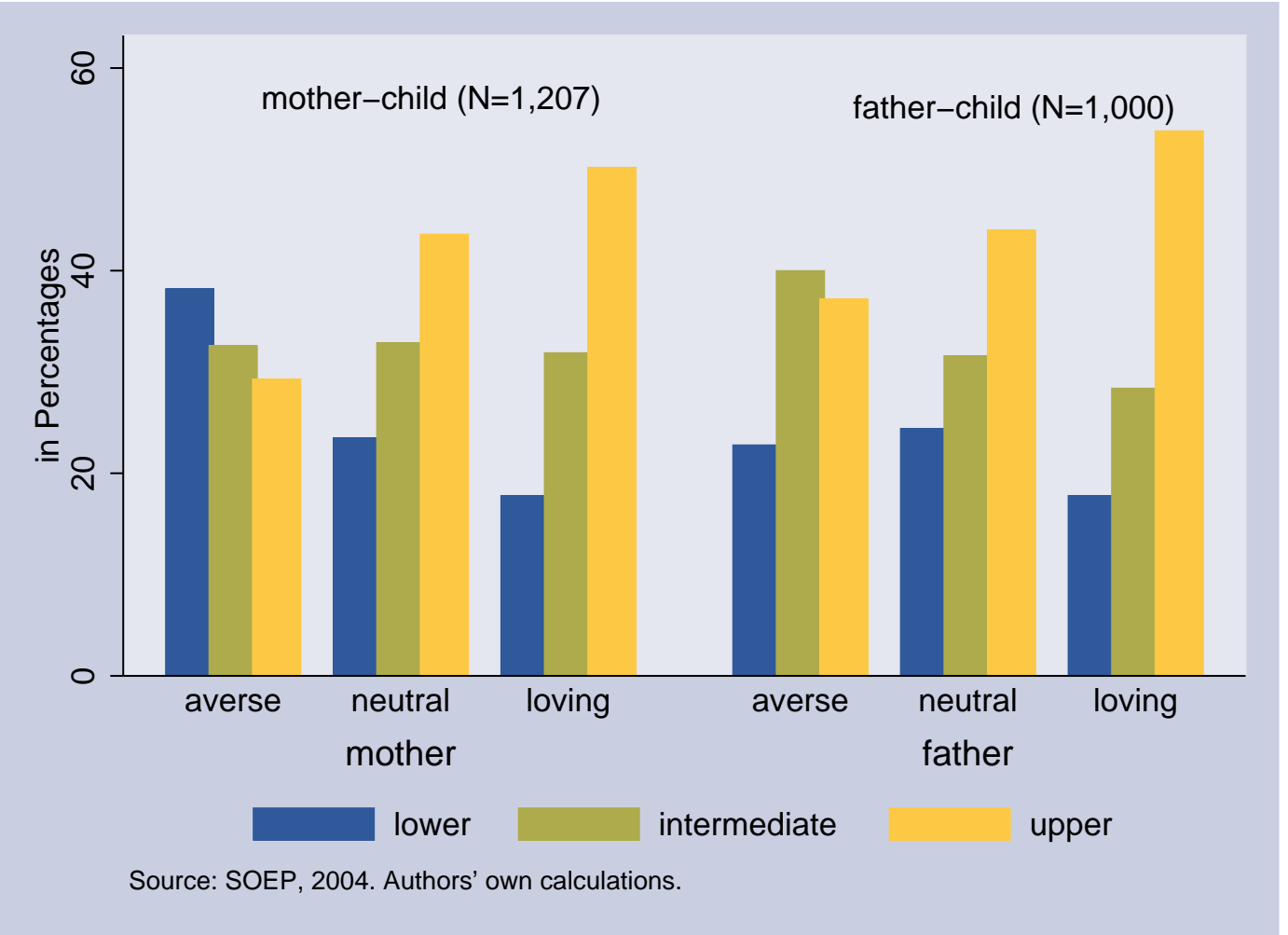

Figure 2: Children's secondary school track by parent's risk attitude 


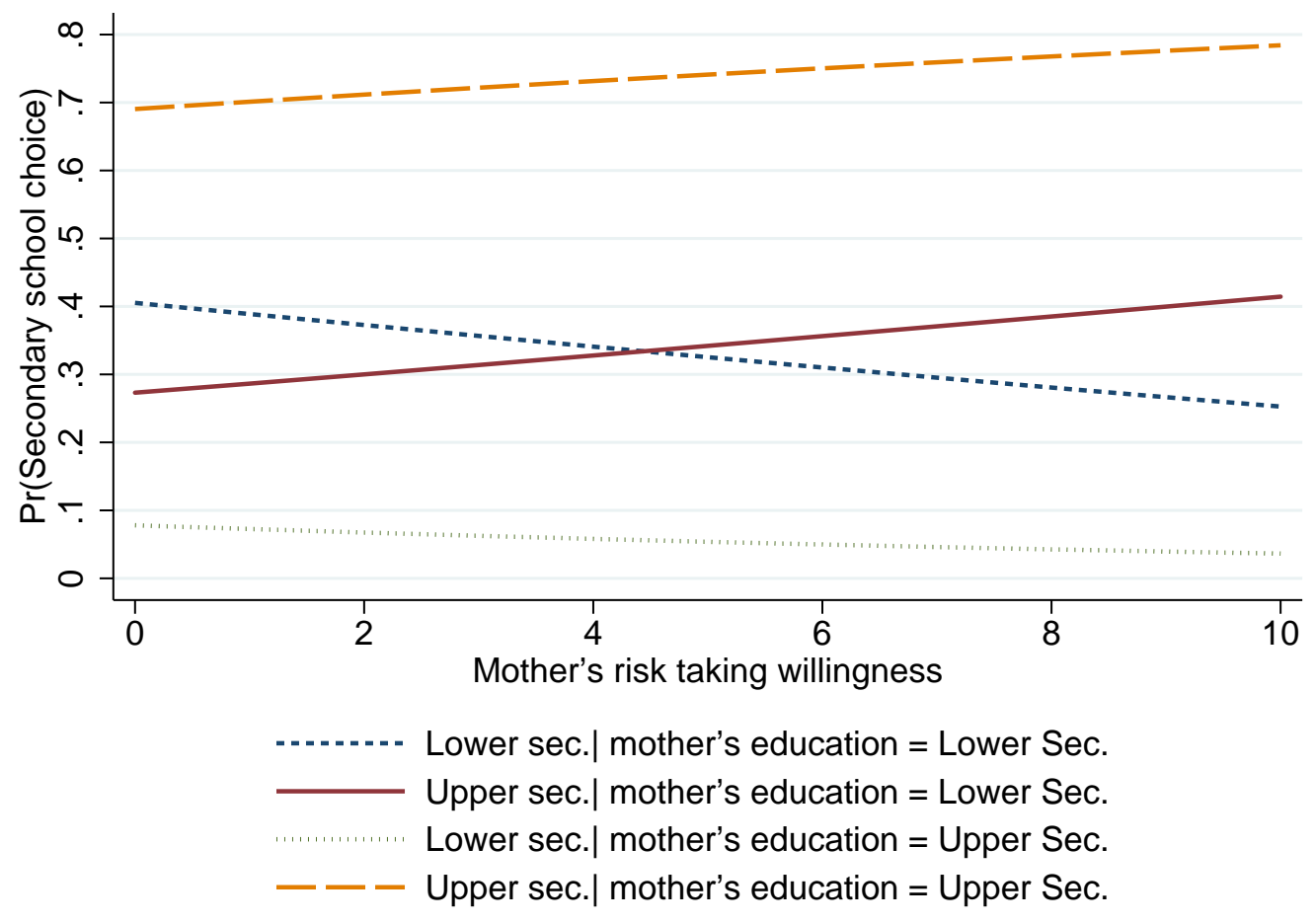

Figure 3: Predicted conditional school track choice probabilities 


\section{References}

Acemoglu, Daron; Pischke, Jorn-Steffen (2001): Changes in the Wage Structure, Family Income and Children's Education. European Economic Review, Vol. 45, No. 4-6, pp. 890904.

Ai, Chunrong; Norton, Edward C. (2003): Interaction Terms in Logit and Probit Models. Economics Letters, Vol. 80, pp. 123-129.

Barsky, Robert B.; Juster, F. Thomas; Kimball, Miles S.; Shapiro, Matthew D. (1997): Preference Parameters and Behavioral Heterogeneity: An experimental Approach in the Health and Retirement Study. Quarterly Journal of Economics, Vol. 112, No. 2, pp. 537-579.

Bartus, Tamás (2005): Estimation of marginal effects using margeff. The Stata Journal, Vol. 5, No. 3, pp. 309-329.

Bellenberg, Gabriele; Hovestadt, Gertrud; Klemm, Klaus (2004): Selektivität und Durchlässigkeit im allgemein bildenden Schulsystem. Rechtliche Regelungen und Daten unter besonderer Berücksichtigung der Gleichwertigkeit von Abschlüssen, universität DuisburgEssen.

Belzil, Christian (2007): Subjective Beliefs and Schooling Decisions, IZA Discussion Paper No 2820. Institute for the Study of Labor.

Belzil, Christian; Leonardi, Marco (2007): Can Risk Aversion Explain School Attainments? Evidence from Italy. Labour Economics, Vol. 14, No. 6, pp. 957-970.

Blanden, Jo; Gregg, Paul (2004): Family Income and Educational Attainment: A Review of Approaches and Evidence from Britain. Oxford Review of Economic Policy, Vol. 20, No. 2, pp. 245-263.

Bonin, Holger; Dohmen, Thomas; Falk, Armin; Huffman, David; Sunde, Uwe (2007): Cross-sectional Earnings Risk and Occupational Sorting: The Role of Risk Attitudes. Labour Economics, Vol. 14, No. 6, pp. 926-937.

Borghans, Lex; Duckworth, Angela L.; Heckman, James J.; Ter Weel, Bas (2008): The Economics and Psychology of Personality Traits. Journal of Human Resources, Vol. 43, No. 4, pp. 972-1059.

Bratberg, Espen; Anti Nilsen, Øivind; Vaage, Kjell (2008): Job Losses and Child Outcomes. Labour Economics, Vol. 15, No. 4, pp. 591-603.

Brown, Sarah; Ortiz, Aurora; Taylor, Karl (2006): Educational Attainment and Risk Preference, sheffield Economic Research Paper Series No 200602. University of Sheffield.

Coelli, Michael B. (2010): Parental Job Loss and the Education Enrollment of Youth. Labour Economics.

Dearden, Lorraine; Machin, Steve; Reed, Howard (1997): Intergenerational Mobility in Britain. The Economic Journal, Vol. 440, pp. 47-66. 
Dohmen, Thomas; Falk, Armin; Huffman, David; Sunde, Uwe; Schupp, Jürgen; Wagner, Gert G. (2005): Individual Risk Attitudes: New Evidence From a Large, Representative, Experimentally-validated Survey, IZA Discussion Paper No 1730. Institute for the Study of Labor. Forthcoming in Journal of European Economic Association.

Enders-Dragässer, Uta; Sellach, Brigitte; Libuda-Köster, Astrid (2004): Zeitverwendung für Hausaufgabenbetreuung. In: Office, Federal Statistical (Ed.) Forum der Bundesstatistik, Vol. 43, Wiesbaden, Altag in Deutschland. Analysen zur Zeitverwendung ed., pp. 149159.

Erikson, Robert; Goldthorpe, John. H. (2002): Intergenerational Inequality: A Sociological Perspective. Journal of Economic Perspectives, Vol. 16, No. 3, pp. 31-44.

Ermisch, John; Francesconi, Marco (2001): Family Matters: Impacts of Family Background on Educational Attainments. Economica, Vol. 68, pp. 137-156.

Greene, William (2010): Testing Hypotheses about Interaction Terms in Nonlinear Models. Economics Letters, Vol. 107, pp. 291-296.

Hartog, Joop; Ferrer-i Carbonell, Ada; Jonker, Nicole (2002): Linking Measured Risk Aversion to Individual Characteristics. Kyklos, Vol. 55, No. 1, pp. 3-26.

Heineck, Guido; Riphahn, Regina T. (2009): Intergenerational Transmission of Educational Attainment in Germany: The last five Decades. Jahrbücher für Nationalökonomie \& Statistik, Vol. 229, No. 1, pp. 36-60.

Henz, Ursula; Maas, Ineke (1995): Chancengleichheit durch die Bildungsexpansion? Kölner Zeitschrift für Soziologie und Sozialpsychologie, Vol. 47, No. 4, pp. 605-633.

Jacob, Marita; Tieben, Nicole (2009): Social Selectivity of Track Mobility in Secondary Schools. European Societies, Vol. 11, No. 5, pp. 747-773.

Kleinjans, Kristin J. (2010): Family Background and Gender Differences in Education Expectations. Economics Letters, Vol. 107, pp. 125-127.

Leonardi, Marco (2007): Do Parents Risk Aversion and Wealth Explain Secondary School Choice? Giornale degli Economisti, Vol. 66, No. 2, pp. 177-206.

Oesterbacka, Eva; Merz, Joachim; Zick, Cathleen D. (2010): Human Capital Investments in Children: A Comparative Analysis of the Role of Parent-Child Shared Time in Selected Countries, IZA Discussion Paper No 5084. Institute for the Study of Labor.

Paulus, Wiebke; Blossfeld, Hans-Peter (2007): Schichtspezifische Präferenzen oder sozioökonomisches Entscheidungskalkül? Zeitschrift für Pädagogik, Vol. 53, No. 4, pp. 491-508.

Pfeifer, Christian (2010): Risk Aversion and Sorting Into Public Sector Employment. German Economic Review.

Pfeifer, Christian (2009): A Note on Risk Aversion and Labour Market Outcomes: Evidence from German Survey Data. Empirical Economics Letter, Vol. 8, No. 3. 
Shaw, Kathryn L. (1996): An Empirical Analysis of Risk Aversion and Income Growth. Journal of Labor Economics, Vol. 14, No. 4, pp. 626-653.

Solon, Gary (1992): Intergenerational Income Mobility in the United States. American Economic Review, Vol. 82, No. 3, pp. 393-408.

Wagner, Gert G.; Frick, Joachim R.; Schupp, Jürgen (2007): The German Socio-Economic Panel Study (SOEP) - Scope, Evolution and Enhancements. Schmollers Jahrbuch, Vol. 127 , No. 1, pp. 139-169.

Weiss, Yoram (1972): The Risk Element in Occupational and Educational Choices. Journal of Political Economy, Vol. 80, No. 6, pp. 1203-1213. 


\section{A Appendix}

Table A.1: Descriptive summary

\begin{tabular}{|c|c|c|}
\hline & $\begin{array}{l}\text { Mother-child } \\
(\mathrm{N}=1,207)\end{array}$ & $\begin{array}{l}\text { Father-child } \\
(N=1,000)\end{array}$ \\
\hline Variable & Mean (Sda) & Mean (Sda) \\
\hline Child's age & $13.26(1.40)$ & $13.22(1.42)$ \\
\hline Parent's age at birth & $27.91(4.96)$ & $31.13(5.70)$ \\
\hline Number of siblings & $1.41(0.91)$ & $1.48(0.91)$ \\
\hline Equiv. net household income (in €) & $3176(1829)$ & $3389(1898$ \\
\hline Male child & 52.94 & 52.50 \\
\hline \multicolumn{3}{|l|}{ Child's secondary school track } \\
\hline Lower track & 25.10 & 22.70 \\
\hline Intermediate track & 32.64 & 32.10 \\
\hline Upper track & 42.25 & 45.20 \\
\hline \multicolumn{3}{|l|}{ Parent's risk attitude } \\
\hline Risk averse & 17.56 & 14.50 \\
\hline Risk neutral & 64.79 & 63.00 \\
\hline Risk loving & 17.65 & 22.50 \\
\hline \multicolumn{3}{|l|}{ Parent's school degree } \\
\hline Lower track & 25.43 & 30.90 \\
\hline Intermediate track & 39.11 & 27.50 \\
\hline Upper track & 24.36 & 28.70 \\
\hline Other & 11.10 & 12.90 \\
\hline \multicolumn{3}{|l|}{ Parent's employment status } \\
\hline Fulltime & 21.46 & 88.10 \\
\hline Part-time & 49.71 & 2.70 \\
\hline Unemployed & 28.83 & 9.20 \\
\hline Migration background & 15.99 & 19.20 \\
\hline Federal state with binding recommendation & 43.74 & 43.00 \\
\hline \multicolumn{3}{|l|}{ Community size of resident } \\
\hline less than 2.000 & 14.25 & 14.10 \\
\hline 2.000-5.000 (East:2.000-20.000) & 12.92 & 12.10 \\
\hline $5.000-20.000$ & 25.27 & 28.10 \\
\hline 20.000-50.000 (East:-100.000) & 17.32 & 17.40 \\
\hline $50.000-100.000$ & 6.13 & 5.80 \\
\hline $100.000-500.000$ & 14.83 & 13.90 \\
\hline 500.000 and more & 9.28 & 8.60 \\
\hline
\end{tabular}

Source: SOEP, 2004. 


\section{Recently published}

No

Author(s)

Title

Date

2/2010 Heckmann, M.

Stellenbesetzungen mit Hindernissen: Auf der

$1 / 10$

Noll, S.

Rebien, M.

Suche nach Bestimmungsfaktoren für den Suchverlauf

3/2010 Schmillen, A. Determinants of lifetime unemployment: A micro data analysis with censored quantile regressions Möller, J.

$\underline{4 / 2010} \begin{aligned} & \text { Schmieder, J.F. } \\ & \text { von Wachter, T. }\end{aligned}$

$2 / 10$ Bender, S. discontinuity estimates from Germany

5/2010 Rebien, M.

The use of social networks in recruiting proc-

$2 / 10$ esses from a firms perspective

6/2010 Drechsler, J. Multiple imputation of missing values in the wave

$2 / 10$ 2007 of the IAB establishment panel

7/2010 Dauth, W. Agglomeration and regional employment growth

$2 / 10$

8/2010 Lietzmann, T. Zur Dauer der Bedürftigkeit von Müttern : Dauer

$3 / 10$ des Leistungsbezugs im SGB II und Ausstiegschancen

9/2010 Jahn, E.J. Looking beyond the bridge: How temporary Rosholm, M agency employment affects labor market out-

$6 / 10$ comes

10/2010 Danzer, A.M. Ethnic concentration and language fluency of Yaman, $\mathrm{F}$. immigrants: quasi-experimental evidence from the guest-worker placement in Germany

$\underline{11 / 2010}$ Yankova, K. Der Selektionsprozess in Maßnahmen der aktiven Arbeitsmarktpolitik: Eine explorative Untersuchung für die deutsche Arbeitsvermittlung

12/2010 Stephan, G. Wages, employment and tenure of temporarily subsidized workers: Does the industry matter?

$13 / 2010$ Klinger, $\mathrm{S}$. The impact of labour market reforms and ecoRothe, $\mathrm{T}$. nomic performance on the matching of shortterm and long-term unemployed

14/2010 Stegmaier, J. Effects of workplace representation on firmprovided further training in Germany

15/2010 Dauth, W. Effects of workplace representation on firmprovided further training in Germany

16/2010 Stüber, $\mathrm{H}$. Does downward nominal wage rigidity dampen Beissinger, $\mathrm{T}$. wage increases?

$17 / 2010$ Schneider, J. Health an work - Indicators and determinnats: Beblo, M. A revised literature and data review for Germany

18/2010 Konle-Seidl, R. Make further vocational training pay * possibilities and limits of promoting transitions by Public Employment Services (PES)

As per: 18.10 .2010

For a full list, consult the IAB website http://www.iab.de/de/publikationen/discussionpaper.aspx 


\section{Imprint}

\section{IAB-Discussion Paper 19/2010}

\section{Editorial address}

Institute for Employment Research

of the Federal Employment Agency

Regensburger Str. 104

D-90478 Nuremberg

\section{Editorial staff}

Regina Stoll, Jutta Palm-Nowak

Technical completion

Jutta Sebald

\section{All rights reserved}

Reproduction and distribution in any form, also in parts,

requires the permission of IAB Nuremberg

\section{Website}

http://www.iab.de

\section{Download of this Discussion Paper}

http://doku.iab.de/discussionpapers/2010/dp1910.pdf

For further inquiries contact the author:

Guido Heineck

Phone +49.911.1793105

E-mail guido.heineck@iab.de

Oliver Wölfel

Phone +49.911.1798963

E-mail oliver.woelfel@iab.de 